\title{
Multipl Kırıklı İki Olguda Yağ Embolisi Sendromu
}

\section{Fat Embolism Syndrome in Two Cases with Multiple Fractures}

\author{
Ülkü Özgül, Ender Gedik, Mustafa Karakaplan, Elif Koç, Erdinç Koca, Türkan Toğal, Mehmet Özcan Ersoy \\ Inönü Üniversitesi Tıp Fakültesi, Anesteziyoloji ve Reanimasyon Anabilim Dalı, Malatya, Türkiye \\ *Inönü Üniversitesi Tıp Fakültesi, Ortopedi ve Travmatoloji Anabilim Dalı, Malatya, Türkiye
}

\section{ÖZET}

Yağ embolisi sendromu, yağ partiküllerinin dolaşıma girmesine bağı olarak solunum sıkıntısı, bilinç bulanıklığı ve peteşiyal döküntülerin ortaya çıktığı bir klinik durumdur. Travmatik, cerrahi ve travma dışı olayları takiben gelişebilir. En sık uzun kemik kırıklarını takiben 24-72 saat içinde gelişir. Klinik tablo hafif olabileceği gibi solunum yetmezliği ve komaya kadar değişebilir. Tanı klinik kriterlere göre konulmaktadır. Spesifik laboratuvar ve radyografik bulgusu yoktur. Tedavide kırığın erken fiksasyonu, sıvı elektrolit dengesinin sağlanması ve hipoksinin giderilmesini içeren destekleyici yaklaşımlar önerilmektedir. Biz bu makalede araç içi trafik kazası sonrası çoğul fraktüre bağlı yağ embolisi sendromu gelişen iki olgunun başarılı tanı ve tedavi sürecini sunmayı amaçladık. (Türk Yoğun Bakım Derneği Dergisi 2012; 10: 23-7) Anahtar Kelimeler: Yağ embolisi, travma

\section{SUMMARY}

Fat embolism is a syndrome which is caused by oil particles introduce into the systemic circulation and consists of respiratory distress, altered consciousness and petechial rashes. It may occur following traumatic, surgical and non-traumatic clinical conditions. The most common occurrence develops following the long bone fractures within 24-72 hours. The clinical picture of syndrome may vary slightly condition as well as respiratory failure and coma. The diagnosis is done based on mostly clinical criteria. There is no specific laboratory and radiographic findings. The suggested supportive approaches in the treatment of this syndrome are early fixation of the fracture, maintenance of fluid and electrolyte balance and treatment of hypoxia. We aimed to present two cases of successful diagnosis and treatment process with fat embolism syndrome following multiple fractures due to in-vehicle traffic accidents. (Journal of the Turkish Society Intensive Care 2012; 10: 23-7)

Key Words: Fat embolism, trauma

Yazışma Adresi/Address for Correspondence: Dr. Ülkü Özgül, Inönü Üniversitesi Tıp Fakültesi, Anesteziyoloji ve Reanimasyon Anabilim Dalı, Malatya, Türkiye Tel.: +90 4223410660 E-posta: ulku.ozgul@inonu.edu.tr Geliş Tarihi/Received: 27.01.2012 Kabul Tarihi/Accepted: 20.03.2012 


\section{Giriș}

Yağ embolisi (YE), genellikle asemptomatik olarak akciğer parankimi ve periferik dolaşımda yağ damlacıklarının bulunması olarak tanımlanır. Yağ embolisi sendromu (YES) ise yağ embolisi sonucu ortaya çıkan klinik belirti ve bulguları tanımlayan bir kavramdır. YES en sık uzun kemik kırıklarından sonra görülür (1). Travmadan sonraki 24-72 saat içerisinde klinik belirtiler ortaya çıkar. YES genellikle bir çoklu sistem bozukluk olarak sunulsa da, en ciddi etkilenen organlar akciğer, beyin, kardiyovasküler sistem ve cilttir (2). Klinik özellikler subklinikten hafif ve fulminan tabloya kadar geniş bir spektrum içerir. Radyolojik ve laboratuvar bulgular nonspesifiktir. Tedavide kırığın erken fiksasyonu, sıvı elektrolit dengesinin sağlanması ve hipoksinin giderilmesini içeren destekleyici yaklaşımlar önerilmektedir $(3,4)$.

Bu olgu sunumunda araç içi trafik kazası sonrasında çoğul fraktüre bağlı yağ embolisi sendromu gelişen iki olgunun tanı ve tedavi sürecini tartışmayı amaçladık.

\section{Olgu 1}

37 yaşında, erkek olgu araç içi trafik kazası nedeniyle acil servisimize getirildi. Sağ ve sol femur, sol tibia ve fibula, sol olekranon fraktürlerine stabilizasyon uygulanan olgu ortopedi servisine yatııldı. Ikinci gün uykuya meyilli olması ve sözel uyarılara cevap vermemesi üzerine Reanimasyon YBÜ'ne kabul edildi. FM'de nabız 125/dk, TA:117/86 $\mathrm{mHg}, \mathrm{SpO}_{2}$ :
\%87, vücut sıcaklığl: $38^{\circ} \mathrm{C}$ ve arteriyel kan gazında (AKG) pH: 7,48, $\mathrm{PaCO}_{2}: 28 \mathrm{mmHg}, \mathrm{PaO}_{2}: 47 \mathrm{mmHg}$ idi (Tablo 1). Olgunun boynunda ve ön aksiller hatta peteşiyal döküntüler vardı (Resim 1). Nörolojik muayenesinde pupilleri izokorik, direkt ve indirekt ışık refleksi +/+, Glasgow Koma Skalası skoru 11/15 $\left(\mathrm{GA}_{4}+\mathrm{M}_{5}+\mathrm{V}_{2}\right)$ olarak tespit edildi. Derin tendon refleksleri normal olarak değerlendirildi. Olgu midazolam ve fentanil ile sedatize edilerek orotrakeal entübe edildi. BIPAP modunda $\mathrm{FiO}_{2}$ : 0,5, PEEP: $5 \mathrm{cmH}_{2} \mathrm{O}$, PEEPASB: $10 \mathrm{cmH}_{2} \mathrm{O}$, f: 14/dk olacak şekilde mekanik ventilatöre bağlandı ve sedasyon (midazolam $5 \mathrm{mg} / \mathrm{saat}$, fentanil $100 \mu \mathrm{g} / \mathrm{saat}$ ) başlandı. Toraks tomografisinde bilateral plevral mayi, sağ lob bazal posterior segmentte pnömonik konsolidasyon ve alt loblarda yaygın buzlu cam görünümü mevcuttu. Beyin tomografisinde anlamlı bir bulgu saptanmadı. Travma öyküsünün olması, klinik durum, arter kan gazı değerleri, döküntülerin varlı̆̆ı, akciğerin radyolojik görüntüsü, cerrahi gerektiren intrakraniyal patoloji olmaması nedeniyle olguya yağ embolisi tanısı konuldu.

Solunum ve dolaşım destek tedavisine ek olarak, olguya pnömoni için sulbaktam-ampisilin ve beyin ödemi için mannitol $4 \times 10 \mathrm{~g}$, enoksaparin 2x6000 IU, metilprednizolon $1 \times 100 \mathrm{mg}$ ve pantoprazol $2 \times 1$ başlandı. Ikinci gün kontrol AKG'da pH: 7,44, $\mathrm{paCO}_{2}: 41 \mathrm{mmHg}, \mathrm{paO}_{2}: 158 \mathrm{mmHg}$ olarak saptandı ve $\mathrm{FiO}_{2}: 0,5^{\prime}$ e düşürüldü. 4. gün antibiyoterapiye yanıt alınamadığından piperasilin-tazobaktam $4 \times 4,5 \mathrm{~g}$ ve siprofloksasin $2 \times 400 \mathrm{mg}$ başlandı. Oksijenasyonunun düzelmesi üzerine 8 . gün hasta ekstübe edilerek operasyon

\begin{tabular}{|c|c|c|c|c|c|c|c|}
\hline GÜN & 1 & 2 & 3 & 4 & 5 & 6 & 7 \\
\hline $\mathrm{pH}$ & 7,42 & 7,34 & 7,38 & 7,39 & 7,40 & 7,34 & 7,40 \\
\hline $\mathrm{PaCO}_{2}(\mathrm{mmHg})$ & 38,7 & 44 & 42,1 & 40,5 & 43,2 & 39,7 & 40,7 \\
\hline $\mathrm{PaO}_{2}(\mathrm{mmHg})$ & 20,4 & 180 & 139 & 120 & 91 & 116 & 130 \\
\hline $\mathrm{SaO}_{2}(\%)$ & 34,6 & 99,2 & 98,7 & 97,5 & 96,6 & 98,3 & 98,7 \\
\hline BK $(103 / m L)$ & 12,1 & 11,1 & 9,2 & 10,8 & 8,6 & 11,1 & 17,6 \\
\hline $\mathrm{Hb}(\mathrm{g} / \mathrm{dL})$ & 9,2 & 8,6 & 10,1 & 9,3 & 8,6 & 7,8 & 11 \\
\hline Htc (\%) & 26,4 & 24,3 & 28 & 26 & 24,5 & 22,1 & 31,5 \\
\hline Plt $\left(10^{3} / \mathrm{mL}\right)$ & 215 & 199 & 148 & 190 & 191 & 248 & 327 \\
\hline PT-INR & 1 & 1 & 1 & 1 & 0,9 & 1 & 1 \\
\hline Glukoz (mg/dL) & 120 & 159 & 151 & 113 & 118 & 129 & 97 \\
\hline AST (U/L) & 36 & 42 & 40 & 29 & & & 46 \\
\hline ALT (U/L) & 21 & 22 & 23 & 16 & & & 30 \\
\hline LDH (U/L) & 302 & 365 & 245 & 200 & & & 120 \\
\hline Lipaz (U/L) & 34 & & 40 & & & & 28 \\
\hline $\mathrm{Ca}(\mathrm{mg} / \mathrm{dL})$ & 7,7 & 7,6 & 8 & 8,2 & 8,1 & 8,4 & 8,2 \\
\hline CRP & 51,3 & & $>100$ & & $>500$ & & \\
\hline
\end{tabular}

BK: beyaz küre, Hb: hemoglobin, Htc: hematokrit, Plt: trombosit, AST: aspartat aminotransferaz, ALT: alanin aminotransferaz, LDH: laktat dehidrogenaz, Ca: kalsiyum, CRP: C-reaktif protein 
planlandı. Yatışının 12. günü ortopedi kliniği tarafından genel anestezi altında açık redüksiyon ve internal fiksasyon operasyonu uygulandı. Postoperatif ekstübe olarak yoğun bakımda takip edildi. Yatışının 15. günü ortopedi kliniğine gönderildi ve 24. günü taburcu edildi.

\section{Olgu 2}

30 yaşında, erkek olgu araç içi trafik kazası nedeniyle başka bir merkeze başvurmuş. Sağ femur fraktürü nedeniyle iki gün ortopedi servisinde yatarak takip edilen hastada bilinç bulanıklığı ve solunum bozukluğu gelişmesi üzerine

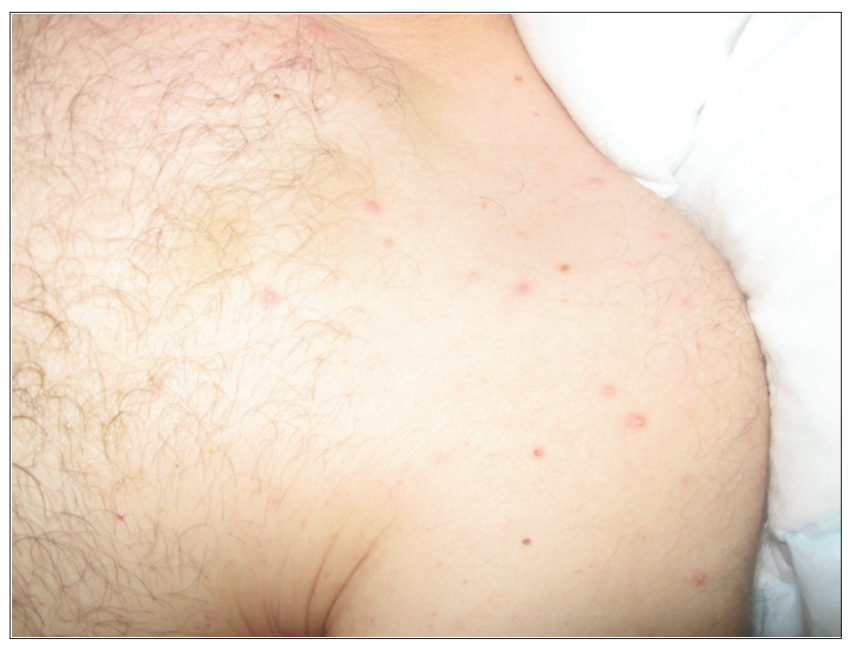

Resim 1. Ciltteki peteşiyal döküntüler çekilen beyin manyetik rezonans görüntülemesinde (MRG) diffüz aksonal hasar (DAH) ön tanısı konularak hastanemize sevk edilmiş. Acil serviste yapılan ilk değerlendirmede olgunun bilinci uykuya meyilli ve solunumu yüzeyeldi. Acil servisteki $A K G$ 'da $\mathrm{pH}$ : 7,43, $\mathrm{PaO}_{2}$ : 54,5 mmHg, $\mathrm{PaCO}_{2}$ : $30,1 \mathrm{mmHg}, \mathrm{SaO}_{2}$ : 86, B.E: -2 mmol/L idi. Olguya maske ile 5 L/dk'dan 02 başlanarak, takip ve tedavi amacıyla Reanimasyon YBÜ'ne kabul edildi. Fizik muayenesinde nabız 110/dk, TA: 160/90 mmHg, SpO2: \%98, vücut sıcaklığı 36,5 ${ }^{\circ} \mathrm{C}$ olarak ölçüldü, yüzde sağ tarafta dermoabrazyon mevcuttu. Boynun her iki yanında ve aksiller bölgede peteşiyal döküntüleri vardı (Resim 2). Sağ uylukta ve sol

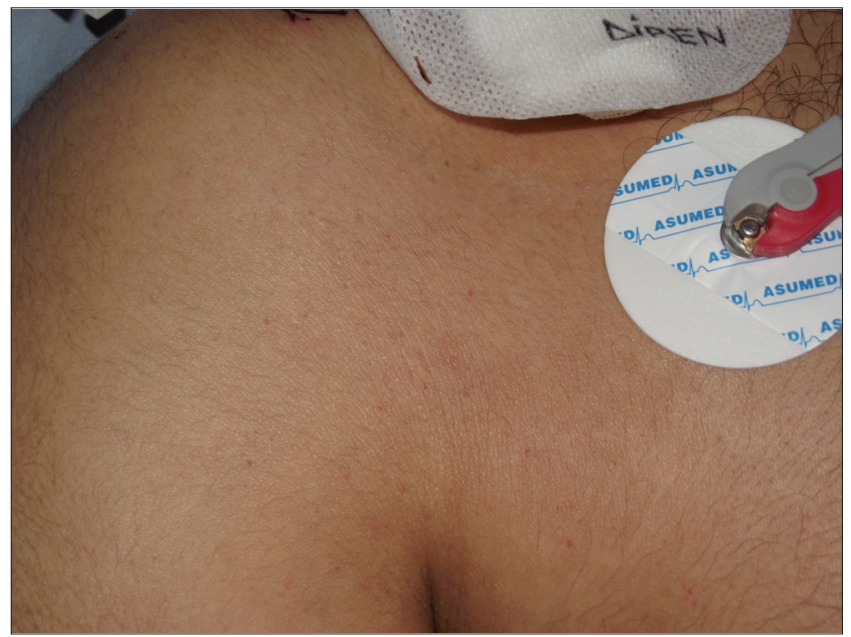

Resim 2. Ciltteki peteşiyal döküntüler

Tablo 2. İkinci olgunun laboratuar değerleri

\begin{tabular}{|c|c|c|c|c|c|c|c|}
\hline GÜN & 1 & 2 & 3 & 4 & 5 & 6 & 7 \\
\hline pH & 7,44 & 7,44 & 7,37 & 7,38 & 7,49 & 7,45 & 7,43 \\
\hline $\mathrm{PaCO}_{2}(\mathrm{mmHg})$ & 30,4 & 36 & 41,5 & 38,1 & 34,7 & 33,1 & 33,6 \\
\hline $\mathrm{PaO}_{2}(\mathrm{mmHg})$ & 64,7 & 158,4 & 99,4 & 95,4 & 96,1 & 94,6 & 120,4 \\
\hline $\mathrm{SaO}_{2}(\%)$ & 93,8 & 99,1 & 95,3 & 94,2 & 95,1 & 93,5 & 98,1 \\
\hline $\mathrm{BK}\left(10^{3} / \mathrm{mL}\right)$ & 12,3 & 9,3 & 9,3 & 10,4 & 11,2 & 13,4 & 14,1 \\
\hline $\mathrm{Hb}(\mathrm{g} / \mathrm{dL})$ & 10,6 & 8 & 11,1 & 11,4 & 12,6 & 12,9 & 14,1 \\
\hline $\operatorname{Htc}(\%)$ & 31,3 & 29 & 32,9 & 34,9 & 38,4 & 39,4 & 42,5 \\
\hline Plt $\left(10^{3} / \mathrm{mL}\right)$ & 121 & 96 & 95 & 156 & 180 & 220 & 293 \\
\hline PT-INR & 1 & 1 & 1 & 1 & 1 & 1 & 1 \\
\hline Glukoz (mg/dL) & 121 & 120 & 120 & 97 & 124 & 103 & 102 \\
\hline AST (U/L) & 102 & 144 & 102 & 127 & 147 & 86 & 50 \\
\hline ALT (U/L) & 42 & 46 & 63 & 130 & 197 & 89 & 53 \\
\hline LDH (mg/dL) & 200 & 380 & 459 & 573 & 613 & 355 & 300 \\
\hline Lipaz (U/L) & 34 & & & 154 & & & \\
\hline $\mathrm{Ca}(\mathrm{mg} / \mathrm{dL})$ & 8,4 & 8,4 & 8,3 & 8,0 & 8,9 & & \\
\hline CRP & 125 & & 25,6 & & & & \\
\hline
\end{tabular}

BK: beyaz küre, Hb: hemoglobin, Htc: hematokrit, Plt: trombosit, AST: aspartat aminotransferaz, ALT: alanin aminotransferaz, LDH: laktat dehidrogenaz, Ca: kalsiyum, CRP: C-reaktif protein 
Türk Yoğun Bakım Derneği Dergisi / Journal of the Turkish Society of Intensive Care 2012;10: 23-7

subkostal bölgede hematom mevcuttu. Sağ bacak atele alınmıştı. Nörolojik muayenesinde pupilleri izokorik, direkt ve indirekt ışık refleksi +/+, Glasgow Koma Skalası skoru 8/15 $\left(\mathrm{GA}_{2}+\mathrm{M}_{4}+\mathrm{V}_{2}\right)$ olarak tespit edildi. Derin tendon refleksleri normal olarak değerlendirildi. Akciğer sesleri normaldi ve herhangi bir patoloji mevcut değildi. Sol göz konjunktivada temporal limbustan 1-2 mm uzaklıkta subkonjunktival kanama odağı tespit edildi.

Olguya radiyal arter kanülü ve santral venöz kateter takıldı. Maske ile $\mathrm{O} 2$ tedavisi devam ederken alınan AKG örneğinde pH: 7,44, $\mathrm{PaO}_{2}: 64,7$ mmHg, $\mathrm{PaCO}_{2}: 30,4 \mathrm{mmHg}, \mathrm{SaO}_{2}:$ 93, B.E: $-2 \mathrm{mmol} / \mathrm{L}$ idi (Tablo 2). Beyin tomografisinde frontopariyetal bölgede ödem görüldü. Toraks tomografisinde herhangi bir patoloji görülmedi. Sağ bacak ortopedi tarafından traksiyona alındı. Travma ve çoklu kırık öyküsünün olması, akut başlangıçlı, ciddi solunum sıkıntısı, peteşiyal döküntülerin varlığı ve DAH'ın radyolojik olarak ekarte edilmesi gibi klinik bulgular nedeniyle olguya yağ embolisi sendromu tanısı konuldu.

Hidrasyon için \%0,45 NaCl $100 \mathrm{~mL} /$ saat ile birlikte pantoprazol 2X1, fenitoin 3X100 mL, enoksaparin 2X6000 IU, mannitol $4 \times 10 \mathrm{~g}$ başlandı. Ikinci gün metilprednizolon $1 \times 100$ $\mathrm{mg}, 20 \mathrm{~mL} / \mathrm{saat}$ hızında parenteral beslenme başlandı. Hemoglobin düzeyinin düşmesi üzerine 2 ünite eritrosit süspansiyonu verildi. 6. gün karaciğer enzimlerinde yükselme olduğundan fenitoin kesildi. Olgu ortopedi tarafından genel anestezi altında operasyona alındı ve postoperatif yoğun bakımda ekstübe edildi. 8. gün mannitol ve metilprednizolon azaltılarak kesildi. Bilinci açık, vital bulguları stabil olan olgu ortopedi servisine devredildi.

\section{Tartışma}

YES klinik olarak ilk kez 1873 yllında von Bergman tarafından femur fraktürlü bir hastada tanımlanmıştır. YES en sık ortopedik yaralanmalardan sonra gelişir. Ayrıca ciddi yanıklar, karaciğer hasarı, kapalı göğüs kalp masajı, kemik iliği transplantasyonu, liposuction, parenteral lipid infüzyonu, pankreatit ve karbon tetraklorid zehirlenmesi gibi durumlardan sonra da bildirilmiştir (5).

YES tipik olarak travmadan sonraki 24-72 saat arasında başlar. Birkaç saat içinde veya birkaç gün sonra ortaya çıkan vakalar da bildirilmiştir. Klasik klinik triadl; solunum sıkıntısı, bilinç bulanıklığı ve peteşiyal döküntüdür. Genellikle ilk ve en sık belirti dispne, taşipne ve hipoksemi şeklinde ortaya çıkan solunum değişiklikleridir (1). Bulger, YES tanısı konulan 27 hastanın \%44'ün de belirli bir süre mekanik ventilasyonun gerektiğini rapor etmiştir (6). Nörolojik değişiklikler hafif konfüzyon ve uyku eğiliminden ciddi konvülsiyonlara kadar değişebilir ve nedeni serebral embolizasyondur. Hemen hemen tüm nörolojik defisitler geçici ve geri dönüşümlü karakterdedir. Peteşiyal döküntüler olguların \%60'ından fazlasında görülmektedir ve genellikle konjunktiva, oral mukoza, vücudun üst tarafında, özellikle boyun ve aksillada yerleşmektedir. Bu döküntüler trombosit fonksiyonlarından bağımsız olarak, cilt kapillerlerinin embolizasyonu ve eritrositlerin damar dışına çıkması nedeniyle ilk 36 saat içinde ortaya çıkar ve 7 günde tamamen yok olurlar (7).

YES'in patogenezi tam olarak bilinmemekle birlikte mekanik ve biyokimyasal nedenler sorumlu tutulmaktadır. Mekanik teoride bütünlüğü bozulan yağlı dokudan veya kemik iliğinden çıkan yağ globüllerinin travmatize bölgede kan dolaşımına geçtiği düşünülmektedir. Biyokimyasal teoride ise plazmaya karışan toksik yağ ara ürünleri sorumlu tutulmaktadır. Her iki mekanizmanın birlikte sorumlu olduğu düşünülmektedir $(3,5)$.

Tanı genellikle klinik bulgulara dayansa da biyokimyasal değişiklikler yararlı olabilir. En sık kullanılan Gurd'un majör ve minör tanı kriterleridir. Major kriterler; aksiller veya subkonjunktival peteşiler, solunumsal yetmezlik ve serebral tutulumdur. Minör kriterler ise $39,4{ }^{\circ} \mathrm{C}$ 'den yüksek ateş, $110 \mathrm{atım} / \mathrm{dk}$ 'dan fazla taşikardi, retinal değişiklikler, idrarda yağ bulunması, açıklanamayan ani hematokrit ve trombosit düşüşü, artmış sedimentasyon, oligüri veya anüri, sarılıktır. Tanı için en az en az iki majör veya bir majör ve dört minör kriter bulunmalıdır $(1,8)$. Olgularımızda çoğul fraktürlü travma sonrası klinik olarak solunum sıkıntısı, peteşiyal döküntüler ve bilinç değişikliklerinin varlığı ile YES tanısı konuldu.

Laboratuar bulgularının hiçbiri \%100 spesifik değildir ve çoklu sistem patolojiyi yansıtabilir. Trombositopeni ve açıklanamayan anemi sıktır. Ikinci olgumuzda tanı konulduktan sonra ikinci günde hemoglobin düşüşü gözlendi. Plazma serbest yağ asit düzeyleri travmayı takiben yükselir ve bunların kalsiyuma afinitesi nedeniyle hipokalsemi gelişebilir. Balgam, idrar veya kanda yağ globüllerinin varlı̆̆ı ve yükselmiş serum lipaz seviyesi YES'in karakteristik olarak kabul edilen bulgularıdır. Bu bulgular tamamen nonspesifiktir ancak bu sendrom olsun veya olmasın travma hastalarında bulunabilir (9).

Akciğer grafisi YES olan hastaların üçte ikisinde anormal bulgular gösterir. En sık rastlanılan bulgu, kar fırtınası olarak tanımlanan, diffüz interstisyel veya alveolar infiltrasyondur. Infiltrasyon yamalı olabilir, periferde hilerden daha sık görülmektedir. Travma hastalarında bronkoalveoler lavaj ile alveolar makrofajlarda yağ damlacıklarının tespit edilmesi ilk 24 saat içinde YES tanısı için spesifik bir metot olarak öne sürülmüştür. Ancak tatmin edici örneklerin elde edilmesinde zorluklar vardır $(1,5,10)$.

YES'de beyin MRG'de, yüksek dansiteli T2 sinyallerinin olması nörolojik bozuklukla koreledir ve MRG bulguları DAH'ı taklit edebilir $(3,11)$. Kumar ve ark. çoğul kırıkl, peteşiyal döküntü ve hafif hipoksemi ile DAH'ı taklit eden MRG bulguları olan bir olguyu YES tanısı ile takip ettiklerini 
bildirmişlerdir (11). Ikinci olgumuz da DAH ön tanısı almıştı ve orta derecede hipoksemisi mevcuttu.

YES'in özel bir tedavisi henüz bulunmamaktadır, tedavinin esası destekleyicidir. Bu nedenle, korunma, erken teşhis ve yeterli semptom yönetimi büyük önem taşır. Uzun kemik kırıklarının 24 saat içinde erken fiksasyonunun YES'in sıkığını azalttığı gösterilmiştir (12).

Destek tedavisinin kapsamında oksijenasyon, ventilasyon, stabil hemodinaminin sağlanması, hidrasyon, gerekirse kan ürünlerinin kullanımı, derin ven trombozu ve strese bağlı gastrointestinal kanama profilaksisi yer alır (8). Birinci olgumuz mekanik ventilatörde 8 gün takip edilirken, ikinci olgumuzda yüz maskesi ile $\mathrm{O}_{2}$ desteği yeterli oldu. Her iki olgumuzda da yeterli hidrasyonu sağlayarak gastrointestinal kanama profilaksisi için pantoprazol $2 \times 1$ ve beyin ödemi için mannitol $4 \times 10 \mathrm{~g}$ verildi, daha sonra azaltılarak kesildi.

Heparin, dekstran ve kortikosteroidler ile tedavilerin morbidite ve mortaliteyi azalttığı gösterilmiştir. Heparin lipaz aktivitesini artırarak lipemik serumu temizlemektedir; bu etkisi nedeniyle tedavi için önerilmektedir. Ancak travmada kanama riskini de artırdığı unutulmamalıdır. Olgularımızda düşük molekül ağırlıklı heparin olan enoksaparin 2x6000 IU semptomlar düzelene kadar uygulandı.

Kortikosteroidler profilaktik olarak verildiğinde yararlı etkileri olabilir. Muhtemelen etki mekanizması pulmoner kapiller membranın stabilizasyonu ile anti-inflamatuar etkiye bağlı perivasküler hemoraji ve ödemin azalmasıdır. Bazı çalışmacılar tedavide de steroidleri önermektedir. Ancak bu konuda yeterli çalışma yoktur. Her iki olgumuza da metilprednizolon kullandık. Aspirinin de kan gazlarını düzelttiği, koagülasyon ve trombosit sayısı üzerine olumlu etki ettiği bildirilmiştir (1).

Sonuç olarak yaşamı tehdit eden YES'de şüpheli klinik bulguların değerlendirilmesi ve hızlı tanı konulması, erken ve uygun yoğun bakım tedavisi mortaliteyi azaltabilir.

\section{Kaynaklar}

1. Mellor A, Soni N. Fat Embolism. Anaesthesia 2001;56:145-54.

2. Habashi NM, Andrews PL, Scalea TM. Therapeutic aspects of fat embolism syndrome. Injury 2006;37 Suppl 4:S68-73.

3. Akhtar S. Fat Embolism. Anesthesiology Clin 2009;27:533-50.

4. Ozyurt Y, Erkal H, Ozay K, Arikan Z. Traumatic fat embolism syndrome: a case report. Ulus Travma Acil Cerrahi Derg 2006;12:254-7.

5. Taviloglu K, Yanar H. Fat Embolism Syndrome. Surg Today 2007;37:5-8.

6. Bulger EM, Smith DG, Maier RV, Jurkovich GJ. Fat embolism syndrome. A 10-year review. Arch Surg 1997;132:435-9.

7. Fulde GW, Harrison P. Fat embolism- a review. Arch Emerg Med 1991;8:233-9.

8. Gurd AR. Fat embolism: an aid to diagnosis. J Bone Joint Surg Br 1970;52:732-7.

9. Georgopoulos D, Bouros D. Fat embolism syndrome: clinical examination is still the preferable diagnostic method. Chest 2003;123:982-3.

10. Bedi P, Chakraberty S, Gupta A. Fat embolism syndrome from subtle to full blown presentation. J Anaesthesiol Clin Pharmacol 2010;26:544-6.

11. Kumar S, Gupta V, Aggarwal S, Singh P, Khandelwal N. Fat embolism syndrome mimicker of diffuse axonal injury on magnetic resonance imaging. Neurol India 2012;60:100-2.

12. Hager CA, Brncick N. Fat embolism syndrome: a complication of orthopaedic trauma. Orthop Nurs 1998;17:41-3, 46, 58. 